\title{
Sublobar minimally invasive surgery vs. stereotactic ablative radiotherapy for early stage non-small cell lung cancer
}

\author{
Carlos Galvez ${ }^{1}$, Sergio Bolufer ${ }^{1}$, Juan-Manuel Corcoles ${ }^{2}$, Francisco Lirio ${ }^{1}$, Julio Sesma ${ }^{1}$, Juan Jose Mafe ${ }^{1}$, \\ Jorge Cerezal ${ }^{1}$
}

${ }^{1}$ Thoracic Surgery Department, Hospital General Universitario Alicante, Alicante 03010, Spain.

${ }^{2}$ Thoracic Surgery Department, Hospital Vinalopo Elche, Elche, Alicante 03293, Spain.

Correspondence to: Dr. Carlos Galvez, Thoracic Surgery Department, Hospital General Universitario Alicante, Alicante 03010, Spain.E-mail: carlos.galvez.cto@gmail.com

How to cite this article: Galvez C, Bolufer S, Corcoles JM, Lirio F, Sesma J, Mafe JJ, Cerezal J. Sublobar minimally invasive surgery vs. stereotactic ablative radiotherapy for early stage non-small cell lung cancer. Mini-invasive Surg 2020;4:86. http://dx.doi.org/10.20517/2574-1225.2020.86

Received: 26 Aug 2020 First Decision: 16 Oct 2020 Revised: 11 Nov 2020 Accepted: 18 Nov 2020 Published: 5 Dec 2020

Academic Editor: Marcelo F. Jimenez Copy Editor: Cai-Hong Wang Production Editor: Jing Yu

\begin{abstract}
Although lobectomy has been traditionally considered the standard treatment for early stage non-small cell lung cancer (NSCLC), lung-sparing resections usually called "sublobar resections" have exponentially increased in their use in the age of minimally-invasive surgery. Sublobar resection, especially anatomical segmentectomy, has shown comparable oncological outcomes in tumors less than $2 \mathrm{~cm}$ in diameter without nodal involvement and distant metastasis. On the other hand, more advanced radiation techniques such as stereotactic ablative radiotherapy, have shown excellent local control rates in stage I NSCLC, with low rates of post-treatment complications, so not only is its role growing in inoperable patients, but also in standard-risk stage I patients. There is a need for multicenter randomized trials addressing specifically this issue. This review aims to collect comparative data about the outcomes of both treatment strategies in early stage NSCLC.
\end{abstract}

Keywords: Thoracic surgery, video-assisted, stereotactic radiation therapy, lung neoplasms

\section{INTRODUCTION}

Lung cancer is still the leading cause of death by cancer with 1.8 million deaths in $2018^{[1]}$. Stage I nonsmall cell lung cancer (NSCLC) shows a 5-year overall survival (OS) ranging from $68 \%$ to $92 \%$ in clinical

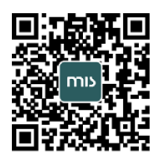


stage $\mathrm{I}^{[2]}$. Since the Lung Cancer Study Group (LCSG) in 1995, lobectomy became the standard pulmonary resection for standard-risk surgical cases $^{[3]}$. Since then, several comparative studies have shown that anatomical sublobar resections (SLR) in selected cases (early stage carcinoma less than $2 \mathrm{~cm}$, in peripheral location without nodal involvement, especially when ground-glass appearance or long duplication time have been observed) shows similar outcomes to lobectomy in terms of disease-free survival (DFS) and $\mathrm{OS}^{[4-8]}$, so the role of SLR is growing exponentially from the high-risk and inoperable patients to also elective cases without pulmonary or cardiovascular compromise (i.e., intentional SLR). Stereotactic ablative radiation therapy (SABR), also known as stereotactic body radiation therapy (SBRT), has also shown a role for inoperable stage I NSCLC with acceptable survival outcomes ${ }^{[9-11]}$ and better postoperative morbidity profiles. However, there is still a lack of prospective randomized trials comparing specifically SLR with SABR, so level 1 evidence is still missing ${ }^{[12]}$. The aim of this review is to collect and discuss all the evidence available regarding this controversial issue.

\section{STEREOTACTIC ABLATIVE RADIATION THERAPY}

SABR differentiates from conventional radiotherapy treatments in delivering larger doses of radiation per session. A typical SABR course for stage I NSCLC consists of 1 to 5 treatments over a 1 to 2 week time period with daily doses of 10 to $34 \mathrm{~Gy}$, while a conventional daily dose of radiation therapy is $2 \mathrm{~Gy}$, which is typically given 5 days a week for approximately 6 weeks.

There are some studies comparing standard radiotherapy and SABR. The SPACE trial randomized 102 patients to receive SABR 66 Gy (3 fractions, 1 week) or three dimensional conformal radiation therapy (3DCRT) 70 Gy (7 weeks). There were no significant differences in terms of OS and progression free survival (PFS) between both arms, with a tendency of improved disease control rate in the SABR arm, as well as less toxicity and better quality of life ${ }^{[13]}$. Li et al. ${ }^{[14]}$ conducted a meta-analysis comparing conventional radiotherapy to SABR in inoperable stage I NSCLC. They found better OS (HR =0.66; $P<$ $0.00001)$, PFS (HR $=0.34 ; P<0.00001)$, and lung-cancer specific survival $(\mathrm{HR}=0.42 ; P<0.00001)$. SABR showed lower rate of adverse events in terms of pneumonitis, esophagitis, and dyspnea. A systematic review published in 2017 also found SABR to be better in terms of survival and local control compared to other techniques of radiotherapy, as well as less toxic ${ }^{[15]}$.

One advantage is the shorter treatment duration. The increased doses of radiation also make SABR more potent and achieve higher rates of local tumor control in stage I NSCLC ${ }^{[12]}$. Indeed, prospective studies and propensity score comparisons have consistently shown 3-year local control rates of approximately $90 \%$ with SABR for stage I NSCLC ${ }^{[11,16,17]}$. Toxicity is low after SABR, with symptomatic radiation pneumonitis (grade $\geq 2$ ) - usually consisting of mild fatigue - ranging between $7 \%-16 \%{ }^{[18,19]}$, chest wall toxicity (pain and rib fractures), decreased pulmonary function, and less commonly, esophagitis, skin irritation, and brachial plexopathy in apical tumors.

One more potential advantage of SABR compared to surgical treatment is that overall quality of life is usually not affected after the treatment. The use of less intense fraction schemes is recommended for more central tumors to avoid more severe adverse effects such as hemoptysis, pneumonia, and respiratory failure.

As SABR induces lung damage and does not resect the tumor, surveillance requires careful imaging tests to assess ground-glass opacities, consolidation, and nodular growth in relation to primary site, but local control rates at 3 years are about $90 \%{ }^{[11,17]}$. Intralobar failures after therapy are $15 \%{ }^{[12]}$ and regional recurrence $9.6 \%{ }^{[20]}$, with distant recurrence as the most common pattern of recurrence, raising up to $25 \%$ of treated cases. 

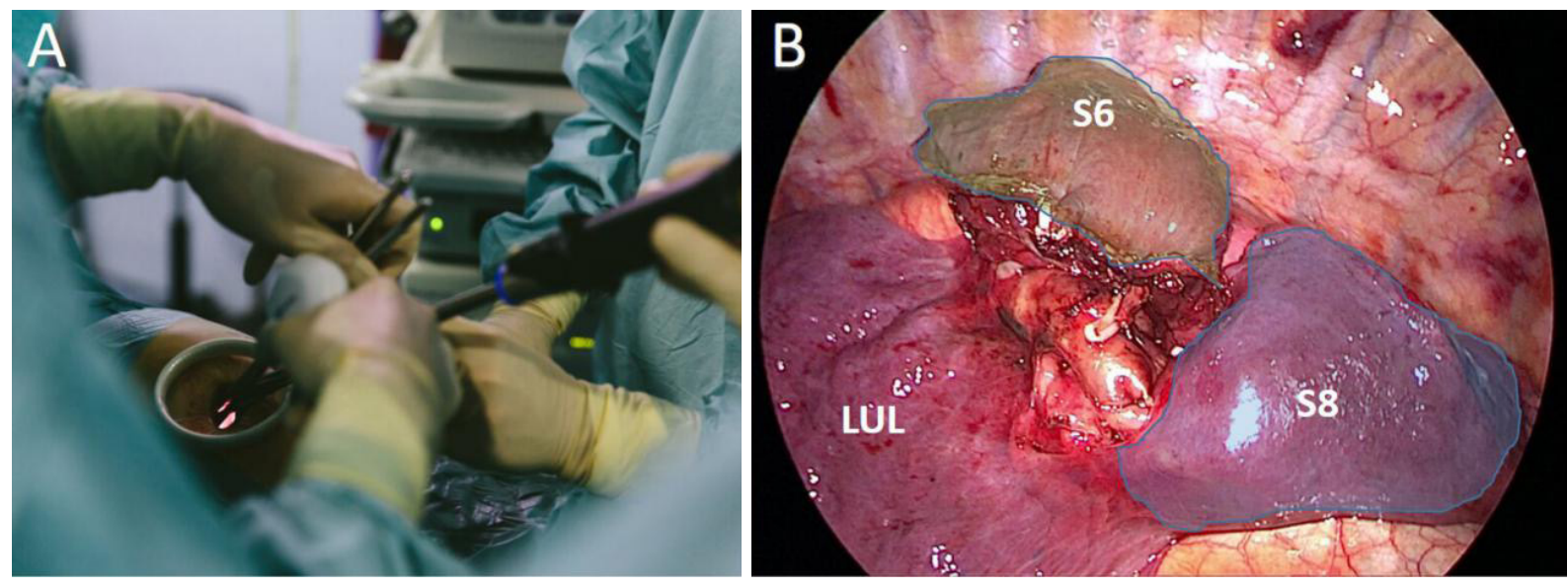

Figure 1. A: uniportal video-assisted thoracic surgery (VATS) instrumentation during left anatomical segmentectomy; B: preservation of left lower lobe $\mathrm{S} 6$ and $\mathrm{S} 8$ segments after S9+10 anatomical segmentectomy by uniportal VATS

\section{THE ROLE OF SUBLOBAR RESECTION IN LUNG CANCER}

Sublobar resections (SLR) include both non-anatomical wedge resections and anatomical resections of segments and subsegments with isolated division of both vascular and bronchial structures (i.e., anatomical segmentectomy). These procedures have specially spread within the last decade due to the diffusion and development of minimally invasive thoracic procedures, and the concept of "lung-sparing surgery", which means preserving as much lung parenchyma as possible [Figure 1$]^{[5,21-24]}$.

Main expected benefit of SLR when compared to lobectomy, is the preservation of higher amount of lung parenchyma, thus the absolute loss of postoperative lung function should be lower than for lobar and supralobar resections. This is why it has been considered an appropriate resection for compromised patients who cannot tolerate a standard lobectomy. Most published studies have not addressed the functional repercussion, but Charloux et al. ${ }^{[25]}$, in 2017 , reported a lower decrease in postoperative forced espiratory volume at first second (FEV1) at 12 months in SLR compared to lobectomy (5\% vs. 11\%, respectively). They also reported lower decrease in global pulmonary function in patients with diminished preoperative lung function who undergone SLR, and a direct relationship between the number of resected segments and functional loss.

Anatomical segmentectomy has been used in the treatment of several pathologies, mainly benign lesions centrally located in the lobe, pulmonary metastasis, and early stage lung cancer ${ }^{[26]}$. In the Lung Cancer Study Group report in 1995, SLR (i.e., anatomical and wedge) showed a higher recurrence and death rate in tumors less than $3 \mathrm{~cm}$ diameter, so lobectomy was set as the standard surgical treatment for early stage lung cancer ${ }^{[3]}$. Since then, many studies have shown that anatomical SLR have comparable DFS and OS than lobectomy for tumors less than $2 \mathrm{~cm}^{[4-8,21]}$. Thus, sublobar anatomical resections have been already included in main clinical guidelines (National Comprehensive Cancer Network -NCCN, European Society of Medical Oncology -ESMO) as an accepted procedure for early stage adenocarcinoma less than $2 \mathrm{~cm}$, in peripheral location without nodal involvement, especially when ground-glass appearance or long duplication time have been observed ${ }^{[27,28]}$. Most published studies are case series or comparative unicentric studies, so there is still a real lack of multicenter studies and randomized trials that specifically address these issues. Two prospective multicenter randomized trials are ongoing now comparing lobectomy to SLR: the Japanese Cooperative Oncological Group (JCOG) 0802 study was launched in Japan in 2009 to evaluate the overall survival of patients after segmentectomy and lobectomy for NSCLC ${ }^{[29]}$. There are 71 centers where 1,100 individuals will be recruited. A similar study is pending in the USA (Cancer and Leukemia Group B 
-CALGB-140503) where 692 people are expected to be recruited ${ }^{[30]}$. These two studies will probably clear some of the actual controversy and might set the indications for SLR in early stage NSCLC.

Studies comparing different approaches for sublobar resections have shown a shorter length of chest tube, shorter hospital stay, and less postoperative pulmonary complications in video-assisted thoracic surgery sublobar anatomical resections when compared to open thoracotomy ${ }^{[26,31-33]}$.

We must differentiate between two groups. The first group includes high-risk patients (FEV $1<50 \%$, diffusion capacity for carbon monoxide -DLCO $<50 \%$ ) or combination of advanced age, impaired pulmonary function, pulmonary hypertension, or decreased left ventricle function ${ }^{[34]}$, where SLR and SABR are potential alternative therapeutic options to standard lobectomy. The second group includes elective intentional SLR in a specific subset of stage I NSCLC when compared to SABR.

\section{COMPARISON OF SUBLOBAR RESECTION AND SABR IN NSCLC}

\section{Sublobar resection and SABR in high-risk or medically inoperable patients}

There are very few studies that specifically address the results of sublobar resections compared to SABR in high-risk operable or medically inoperable lung cancer patients [Table 1]. When we consider this comparison, not only should oncological outcomes in terms of overall survival or loco-regional control be addressed, but also postoperative morbidity and mortality, patient's quality of life during and after treatment administration, and ability to deliver therapy (especially for SABR $)^{[41]}$.

There are important factors that make these studies difficult that must be mentioned. First, the definition of local recurrence is usually different in surgical series than in SABR studies. Surgical series usually define local recurrence as recurrence in the staple line, in the chest wall, in the same lobe, or in the hilar or even mediastinal lymph nodes. On the other hand, SABR series define local recurrence only as recurrence in the primary tumor site ${ }^{[41]}$. Second, patient population should be similar in both arms, because most SABR series have address only inoperable and high-risk operable patients who can die due to their comorbidities before a recurrence appears, while SLR have usually included both standard-risk and high risk operable patients. Third, adverse events should be homogenized because the chronological pattern of adverse events is different between these two therapeutic alternatives. While adverse events usually occur early in surgical patients, adverse events usually appear later in SABR patients. Fourth, in SABR patients, surgical nodal staging is usually not performed, especially when dealing with stage I tumors less than $2 \mathrm{~cm}$ in diameter ${ }^{[35]}$, so lymph node assessment is limited to pretreatment imaging studies (e.g., chest CT and PET scan).

Yendamuri et al ${ }^{[36]}$, in 2007, retrospectively analyzed 160 clinical stage I NSCLC patients with contraindication for lobectomy (68 wedge resection and $923 \mathrm{D}$ conformal radiation therapy). They found a trend to better outcomes with limited resection with OS $(P=0.010)$ and recurrence-free survival (RFS) $(P$ $=0.000)$ in the univariate analysis; however, that trend was only observed to be significant in the RFS in the multivariate analysis $(P=0.002)$. After a propensity matching score analysis, these differences in OS and RFS disappeared between both groups, so they concluded that both treatments were comparable.

In 2013, Mahmood et al. ${ }^{[42]}$ performed a Best Evidence Topic analysis comparing SABR with SLR in clinical stage I high-risk NSCLC patients. They only included 3 comparative studies. The first one ${ }^{[37]}$ found higher mean survival (4.1 years vs. 2.9 years) in the SLR group, and higher 4-year survival (51.3\% vs. 30.1\%). The second, Grills et al ${ }^{[38]}$, reported higher rate of local recurrence with wedge resection compared to SABR (20\% vs. $4 \%)$. OS was higher after wedge resection $(87 \%$ vs. $72 \% ; P=0.01)$, but cause-specific survival showed no differences ( $94 \%$ vs. $93 \%$; $P=0.53$ ). In the third, Forquer et al. ${ }^{[39]}$ found no differences in 3 -year survival were found, but they found higher median survival in SLR compared to SABR (55 months vs. 37 months), although no differences in cancer specific survival were observed. Dr. Scanagatta ${ }^{[43]}$ commented the 
Table 1. Summay of comparative studies between SLR and SABR in high-risk or inoperable NSCLC

\begin{tabular}{|c|c|c|c|}
\hline $\begin{array}{l}\text { Author, year, country } \\
\text { study type (level evidence) }\end{array}$ & Groups & Results & Comments \\
\hline $\begin{array}{l}\text { Yendamuri et al. }{ }^{[36]} \text { (2007) } \\
\text { (USA) } \\
\text { Retrospective observational } \\
\text { study (level 3) }\end{array}$ & $\begin{array}{l}160 \text { stage I NSCLC } \\
\text { (contraindication for lobectomy) } \\
\text { - } \quad 68 \text { wedge resection } \\
\text { - } \quad 923 \text { D conformal radiation } \\
\quad \text { therapy }\end{array}$ & $\begin{array}{l}\text { Univariate analysis: } \\
\text { - } \quad \text { Better OS }(P=0.010) \text { and } \\
\quad \text { RFS }(P=0.000) \text { with wedge } \\
\text { resection } \\
\text { Multivariate analysis: } \\
\text { - } \quad \text { Better RFS }(P=0.002) \\
\text { Propensity score matching } \\
\text { - } \quad \text { No differences }(O S P= \\
0.609 ; \text { RFS } P=0.701)\end{array}$ & $\begin{array}{l}\text { In high-risk patients with NSCLC, } \\
\text { limited resection has } \\
\text { a tendency towards improved } \\
\text { outcome. } \\
\text { Propensity } \\
\text { matched analysis did not show a } \\
\text { clear benefit for a wedge }\end{array}$ \\
\hline $\begin{array}{l}\text { Forquer et al. }{ }^{[39]} \text { (2007) } \\
\text { (USA) } \\
\text { Retrospective analysis }\end{array}$ & $\begin{array}{l}38 \text { stage I NSCLC: } \\
-\quad 19 \text { SLR } \\
-\quad 19 \text { SBRT }\end{array}$ & $\begin{array}{l}\text { 3-year survival: } \\
\text { - SLR } \\
\text { - SBRT ( } P=\text { NS) } \\
\text { Median survival: } \\
\text { - SLR } 55 \text { months } \\
\text { - SBRT } 37 \text { months }(P=\text { NS) } \\
\text { Cancer-specific deaths: } \\
\text { - SLR } 2 / 10 \\
\text { - SBRT } 2 / 9\end{array}$ & $\begin{array}{l}\text { SLR and SBRT have similar survival } \\
\text { results, although a trend towards } \\
\text { better median survival in SLR }\end{array}$ \\
\hline $\begin{array}{l}\text { Grills et al. }{ }^{[38]} \text { (2010) (USA) } \\
\text { Retrospective observational } \\
\text { study (level 3) }\end{array}$ & $\begin{array}{l}\text { 124 T1-2NO NSCLC: } \\
-\quad 69 \text { wedge resection } \\
-\quad 58 \text { SBRT }\end{array}$ & $\begin{array}{l}\text { Local recurrence (LR): } \\
\text { - wedge } 20 \% \\
\text { - SBRT } 4 \%(P=0.07) \\
\text { Overall survival: } \\
\text { - Wedge } 87 \% \\
\text { - SBRT } 72 \%(P=0.01) \\
\text { Cancer specific survival (CSS): } \\
\text { - Wedge } 94 \% \\
\text { - SBRT } 93 \%(P=0.53)\end{array}$ & $\begin{array}{l}\text { SBRT and wedge } \\
\text { resection are reasonable treatment } \\
\text { options for Stage I NSCLC patients } \\
\text { who are not } \\
\text { suitable for lobectomy. } \\
\text { Wedge resection has higher LR but } \\
\text { higher OS. } \\
\text { SBRT and surgery have comparable } \\
\text { CSS }\end{array}$ \\
\hline $\begin{array}{l}\text { Puri et al. }{ }^{[37]} \text { (2012) (USA) } \\
\text { Retrospective observational } \\
\text { study (level 3) }\end{array}$ & $\begin{array}{l}\text { 114 stage I NSCLC: } \\
-\quad 57 \text { SLR } \\
-\quad 57 \text { SBRT }\end{array}$ & $\begin{array}{l}\text { Median survival: } \\
\text { - SLR: } 4.1 \text { years } \\
\text { - SBRT: } 2.9 \text { years } \\
\text { 4-year survival: } \\
\text { - SLR: } 51.4 \% \\
\text { - SBRT: } 30.1 \% \\
\text { Cost } \\
\text {-SLR } \$ 17629 \\
\text {-SBRT } \$ 14153\end{array}$ & $\begin{array}{l}\text { SLR is more cost-effective due to } \\
\text { longer OS }\end{array}$ \\
\hline $\begin{array}{l}\text { Varlotto et al. }{ }^{[16]} \text { (2013) } \\
\text { (USA) } \\
\text { Retrospective study } \\
\text { (databases) }\end{array}$ & $\begin{array}{l}317 \text { NSCLC: } \\
\text { - } \quad 48 \text { wedge } \\
\text { - } \quad 132 \text { lobectomy } \\
\text { - } \quad 137 \text { SBRT }\end{array}$ & $\begin{array}{l}\text { 5-year OS: } \\
\text { - } \quad \text { SLR } 86.3 \% \\
-\quad \text { SBRT } 31.7 \%(P=0.003)\end{array}$ & $\begin{array}{l}\text { Better OS in wedge resection, but } \\
\text { not significant in the multivariate } \\
\text { analysis }\end{array}$ \\
\hline $\begin{array}{l}\text { Matsuo et al. }{ }^{[40]} \text { (2014) } \\
\text { (Japan) } \\
\text { Retrospective observational } \\
\text { study (level 3) }\end{array}$ & $\begin{array}{l}180 \text { stage I NSCLC (high-risk for } \\
\text { lobectomy): } \\
\text { - } \quad 65 \text { SLR } \\
\text { - } \quad 115 \text { SBRT }\end{array}$ & $\begin{array}{ll}\text { 5-year OS } \\
-\quad \text { SLR 55.6\% } \\
-\quad \text { SBRT } 40.4 \%(P=0.124)\end{array}$ & $\begin{array}{l}\text { SBRT can be an alternative } \\
\text { treatment option to SLR in high- } \\
\text { risk patients who cannot tolerate } \\
\text { lobectomy because of medical } \\
\text { comorbidities }\end{array}$ \\
\hline $\begin{array}{l}\text { Ackerson et al. }{ }^{[9]} \text { (2018) } \\
\text { (USA) } \\
\text { Retrospective observational } \\
\text { study (level 3) }\end{array}$ & $\begin{array}{l}\text { 221 stage I NSCLC: } \\
\text { - } \quad 151 \text { SLR (105 wedge and } 46 \\
\text { segmentectomies) } \\
\text { - } \quad 70 \text { SBRT }\end{array}$ &  & $\begin{array}{l}\text { SBRT and sublobar resection } \\
\text { provide similar rates of local } \\
\text { tumor control and overall clinical } \\
\text { outcomes in stage I NSCLC }\end{array}$ \\
\hline
\end{tabular}




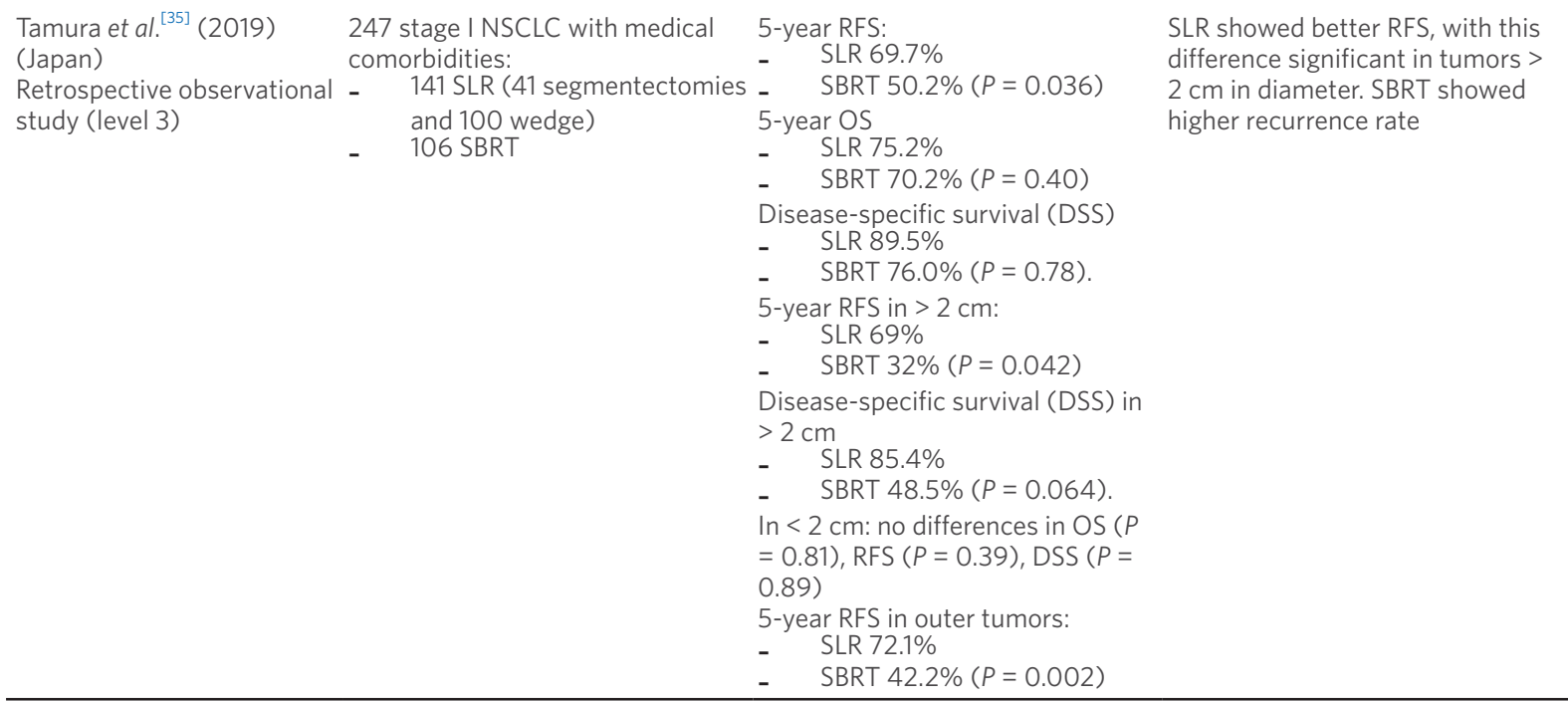

NSCLC: non-small cell lung cancer; OS: overall survival; RFS: recurrence-free survival; SLR: sublobar resection; SABR: stereotactic ablative radiotherapy; SBRT: stereotactic body radiation therapy; DSS: disease-specific survival; CSS: cancer-specific survival; DFS: disease-free survival

potential benefit of the CyberKnife technology applied to SABR for these patients because it has a synchrony system for the respiratory movements with an accuracy of $2 \mathrm{~mm}$ or less, that might decrease collateral damage to surrounding parenchyma, as a potential issues for research.

Varlotto et al. ${ }^{[16]}$ reported, in 2013 from cancer databases, 48 SLR and 137 SABR patients with a median follow-up of 2.2 years. OS was superior in SLR compared with SABR matched pairs $(86.3 \%$ and $31.7 \%$ for SLR and SABR at 5 years, respectively, $P=0.003$ ). However, the multivariate analysis that included propensity scores as a covariate showed that the hazard ratio for OS was not significant, so no significant differences between both treatments could be drawn.

A retrospective analysis performed by Matsuo et al.$^{[40]}$, in 2014, included patients with clinical stage I NSCLC at high-risk for lobectomy who underwent either SABR or SLR. After a propensity matching score analysis, there was no statistically significant difference in 5 -year OS between both treatments $(40.4 \% v s$. $55.6 \% ; P=0.124)$.

Ackerson et al. ${ }^{[9]}$, in 2018, retrospectively compared 151 SLR (105 wedge and 46 segmentectomies) in clinical stage I patients not amenable to lobectomy, with 70 patients treated with SABR (89\% deemed medically inoperable by surgeons due to severe decrease in pulmonary function or severe cardiovascular disease). Radiotherapy patients were older $(P=0.019)$, had higher Charlson comorbidity index score $(P<$ $0.001)$, had lower pulmonary function in terms of FEV 1 and DLCO $(P=0.001$ and $P<0.001$, respectively), and larger tumors $(P<0.001)$, making comparison problematic. OS and DFS were superior in the surgical group (3-year OS 63\% vs. 35\%, $P<0.001$; 3-year DFS $42 \%$ vs. 29\%, $P=0.004$ ), but there were no differences in cancer-specific disease-free survival $(P=0.84)$. After adjusting for imbalances in baseline characteristics of both groups, there was no difference in overall survival between surgery and SABR (HR $=1.20 ; 95 \% \mathrm{CI}$ : 0.74-1.95; $P=0.46)$. 3-year freedom from local recurrence was similar between both treatments $(90 \% v s$. $85 \%, P=0.71)$. In the surgical group, $23 \%$ developed postoperative complications, while in the SABR group there were complications in $17 \%$.

A retrospective study of Tamura et al ${ }^{[35]}$, in 2019, compared 106 SABR patients with 141 SLR (100 wedge and 41 anatomical segmentectomies) in clinical stage I NSCLC with medical comorbidities (e.g., poor 
pulmonary function, chronic lung disease, old age, and poor performance status). The 5-year RFS was higher in the SLR group ( $69.7 \%$ vs. 50.2\%; $P=0.036)$, but there were no statistically differences in OS ( $75.2 \%$ vs. $70.2 \% ; P=0.40)$ or in disease-specific survival ( $89.5 \%$ vs. $76.0 \% ; P=0.78)$. In tumors larger than $2 \mathrm{~cm}$ in diameter, RFS and disease-specific survival were higher in the SLR group, while in tumors less than $2 \mathrm{~cm}$ in diameter there were no differences in OS, RFS, or disease-specific survival. Local recurrence rate was higher in the SABR group $(P=0.0082)$ in tumors located in the outer third of lung parenchyma, while no significant difference could be seen in the internal group. Regional recurrence and distant metastasis rate showed no differences between both groups.

None of these studies was randomized, so the evidence is limited, but it seems that in these compromised patients, both treatments show similar overall survival, with a trend to better local control in surgical patients, especially with tumors larger than $2 \mathrm{~cm}$ or in the outer third of the lung.

The SABRTooth trial was a UK multi-center, randomized controlled feasibility study targeting patients with peripheral stage I NSCLC considered to be at higher risk of surgical complications. They planned to randomize 54 patients 1:1 to SABR or surgery. Between July 2015 and January 2017, 318 patients were considered for the study but only 106 assessed as eligible (33.3\%), from whom 24 patients $(22.6 \%)$ were randomized to SABR $(n=14)$ or surgery $(n=10)$. The main reason for nonparticipation was treatment preference with $43(41 \%)$ preferring non-surgical treatment and 19 (18\%) preferring surgery. The average monthly recruitment rate was 1.7 patients against an initial target of 3. Only 15 patients underwent their allocated treatment, 12 SABR and 3 surgery, proving the difficulty of setting a randomized trial in this highrisk population ${ }^{[4]]}$.

\section{Sublobar resection and SABR in operable stage I NSCLC}

Despite lobectomy still being the standard treatment for early stage lung cancer ${ }^{[28,45]}$, sublobar resections, mainly anatomical segmentectomy, have progressively increased for treating stage I NSCLC less than $2 \mathrm{~cm}$ without nodal involvement due to similar oncological outcomes in terms of local control and overall survival $^{[4-8]}$. Sometimes, patients refuse surgical treatment due to personal concerns or frightens when facing the postoperative risks, so SABR is the most common alternative offered in these situations. It has shown optimal local control (92\% 5-year local progression-free rate in stage IA, and $73 \%$ in stage IB) and acceptable 5 -year overall survival rates $\left(72 \%\right.$ in stage $\mathrm{IA}$, and $63.2 \%$ in stage $\mathrm{IB}^{[46]}$ ). But which are the comparative results of these treatments in those stage I patients where SLR can be offered?

A meta-analysis was published in 2017 comparing surgery (i.e., lobectomy and SLR) with SABR in stage I $\mathrm{NSCLC}^{[47]}$. No randomized trial was included, but 12 cohort studies, with more than 13,000 patients. SABR showed worse outcomes in terms of 3-year survival $(\mathrm{RR}=0.78 ; P=0.001)$ and $\mathrm{OS}(\mathrm{HR}=1.60 ; P<0.001)$, but when a subgroup analysis was performed comparing SLR with SABR (4 of 12 studies), there were no significant differences in terms of 3-year survival, OS, and 3-year locoregional control. This meta-analysis did not distinguish between wedge or anatomical segmentectomy, and also included studies dealing with the elderly or high-risk patients, so this heterogeneity highlights the need for careful conclusions.

Chen et al $^{[48]}$ published another meta-analysis of 16 propensity score studies including more than 19,000 patients. Results favored SLR compared to SABR (HR $=1.28$; 95\% CI: 1.06-1.56) in terms of OS, but there were no statistical differences in terms of lung cancer specific survival (HR = 1.22; 95\% CI: 0.95-1.57). There was also no distinction between wedge and anatomical segmentectomy, and the meta-analysis also included comparative studies in the elderly or high-risk surgical patients.

Iguchi et al. ${ }^{[49]}$ published a single-center retrospective evaluation of the results of 3 modalities in stage I NSCLC (i.e., radiofrequency ablation, SABR, and SLR). SLR has achieved longer survival, but after adjustment, only reduce HR of disease progression and death of any cause were observed $(P=0.038)$. 
A retrospective analysis of 4,069 US veterans by Bryant et al. ${ }^{[50]}$, with 449 SABR and 634 SLR (414 wedge and 220 anatomical segmentectomies), found no statistical differences in cancer-specific survival ( $\mathrm{HR}=1.25$; 95\%CI: $0.93-1.68 ; P=0.15)$ or OS (HR $=1.17$; 95\%CI: 0.90-1.53; $P=0.85)$ between both treatments, while lobectomy was superior to SABR.

A National Cancer Database study was conducted by Wu et al. ${ }^{[51]}$. After propensity score matching, 9,967 patients treated by SABR resulted in shorter OS compared to 9,967 SLR patients. Both wedge resection and anatomical segmentectomy showed longer OS, whereas segmentectomy patients had longer median survival than wedge patients ( 71.4 years vs. 58.0 years; $P<0.001$ ). In tumors less than $2 \mathrm{~cm}$ in diameter, SABR had higher hazard of mortality than SLR $(P<0.001)$.

A meta-analysis by Cao et al. ${ }^{[7]}$, in 2019, compared SABR and surgery in NSCLC. There was no limitation to early stage NSCLC, and no subgroup analysis in stage I. In the subgroup analysis of sublobar resections, OS was superior in SLR compared to SABR in unmatched patients from 6 studies (OR $=1.54$; 95\%CI: 1.36 $1.75 ; P<0.00001)$, but there were insufficient matched patients to perform a meta-analysis. All these studies are summarized in Table 2 .

There is one randomized trial in course, the VALOR trial (NCT02984761), comparing anatomical pulmonary resection (lobectomy and segmentectomy) with SABR in stage I biopsy-proven NSCLC. The estimated accrual is 670 patients and the primary endpoint is 5-year OS, and the expected completion date is 2027 .

Guidelines of the American Society of Radiation Oncology ${ }^{[52]}$ do not recommend SABR out of a clinical trial in patients with standard operative risk for lobectomy with systematic lymph node dissection. But as many recent studies advocate for lung-preserving SLR in early stages, the question that remarks unanswered is: In those cases, does SABR constitutes an alternative treatment due to better toxicity profile? Or does the advantages of a surgical exploration (e.g., visualization of cavity and other lobes, lymph node assessment, and resection of primary lesion) makes SLR the optimal treatment?

\section{Sublobar resection and SABR in nodules detected during lung cancer screening tests}

The National Lung Screening Trial (NLST) ${ }^{[53]}$ found that $68 \%$ of NSCLC rightly diagnosed by CT were stage $\mathrm{I}^{[12]}$, and reported a $20 \%$ decrease in lung cancer specific mortality $(P=0.004)$ and $6.7 \%$ in overall mortality $(P=0.02)$ compared to the radiography group. Several other lung screening trials have supported these results ${ }^{[5]}$. But not all these newly diagnosed small nodules are malignancies, so it raises the controversy of how to deal with these nodules. Surgical resection offers the possibility of assessing hilar and mediastinal lymph nodes (20\% occult nodal metastasis in clinical stage $\mathrm{I}^{[12,55]}$, although lower in screening-detected tumors $^{[56]}$ ), and also obtains a complete nodule resection for assessing pathological prognostic factors. Other potential disadvantages of SABR when compared to surgery are the overtreatment of false positive lesions, and the fact that nodules are not resected, so follow-up implies the careful performance and analysis of residual scar lesions and their potential growth ${ }^{[55]}$.

An issue that makes SABR an attractive alternative in screening detected tumors is the toxicity profile, which seems to be less severe for SABR. Also, a mean 30-day mortality of $10 \%$ in severe chronic obstructive pulmonary disease stage I NSCLC after surgery makes a less toxic algorithm appear as a desirable option ${ }^{[57]}$.

For peripheral screen detected early stage NSCLC in patients amenable to surgery, this seems the most suitable option because it also offers accurate staging, definitive diagnosis, and pathological prognostic factors assessment ${ }^{[5]}$. In patients at high-risk for surgery or patients who are inoperable, SABR should be offered to patients in a shared decision-making process as it provides similar disease control with better 
Table 2. Summay of comparative studies between SLR and SABR including operable NSCLC

\begin{tabular}{|c|c|}
\hline $\begin{array}{l}\text { Author, year, country } \\
\text { Study type (level evidence) }\end{array}$ & Groups \\
\hline $\begin{array}{l}\text { Deng et al. }{ }^{[47]} \text { (2017) } \\
\text { (China) } \\
\text { Meta-analysis (level } \\
\text { evidence 1) }\end{array}$ & $\begin{array}{l}13.598 \text { stage I NSCLC three } \\
\text { strategies (SBRT, SLR, lobectomy } \\
12 \text { cohort studies ( } 4 \text { studies } \\
\text { comparative with SLR) } \\
\text { No randomized trial }\end{array}$ \\
\hline $\begin{array}{l}\text { Chen et al. }{ }^{[48]} \text { (2018) } \\
\text { (Canada) } \\
\text { Meta-analysis (level } \\
\text { evidence 1) }\end{array}$ & $\begin{array}{l}19.882 \text { patients } \\
16 \text { propensity score studies } \\
\text { No randomized trial }\end{array}$ \\
\hline $\begin{array}{l}\text { Iguchi et al. }{ }^{[49]} \text { (2020) } \\
\text { (Japan) } \\
\text { Retrospective observational } \\
\text { study (level 3) }\end{array}$ & $\begin{array}{l}289 \text { patients stage I NSCLC: } \\
\text { - } \quad 38 \text { RF ablation } \\
\text { - } \quad 58 \text { SBRT } \\
\text { - } \quad 193 \text { SLR }\end{array}$ \\
\hline
\end{tabular}

\begin{tabular}{|c|c|c|c|}
\hline & & 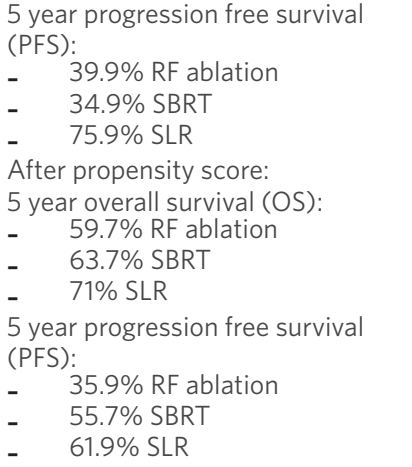 & \\
\hline $\begin{array}{l}\text { Bryant et al. }{ }^{[50]} \text { (2018) } \\
\text { (USA) } \\
\text { Retrospective observational } \\
\text { study (level 3) }\end{array}$ & $\begin{array}{l}\text { 1,083 early stage NSCLC: } \\
-\quad 634 \text { SLR } \\
-\quad 449 \text { SBRT }\end{array}$ & $\begin{array}{l}\text { Cancer-specific survival (CSS): } \\
\text { - } \quad \text { No differences }(H R=1.25 ; \\
\quad 95 \% C l: 0.93-1.68 ; P=0.15) \\
\text { Overall survival (OS): } \\
\text { - } \quad \text { No differences }(H R 1.17 ; \\
\quad 95 \% C l: 0.90-1.53 ; P=0.85)\end{array}$ & $\begin{array}{l}\text { Lobectomy improves survival } \\
\text { comparing to SBRT in early } \\
\text { stage NSCLC, while there are no } \\
\text { differences between SLR and SBRT }\end{array}$ \\
\hline $\begin{array}{l}\text { Wu et al. }{ }^{[51]} \text { (2020) (China) } \\
\text { Retrospective study } \\
\text { (databases) }\end{array}$ & $\begin{array}{l}\text { 19.934 NSCLC: } \\
-\quad 9.967 \text { SLR } \\
-\quad 9.967 \text { SBRT }\end{array}$ & $\begin{array}{l}\text { Overall survival (OS): } \\
-\quad \text { SLR } 60.4 \text { months } \\
\text { - } \quad \text { SBRT } 40.5 \text { months }(H R= \\
\quad \begin{array}{l}\text { 1.559; } 95 \% \mathrm{Cl}: 1.497-1.623 ; P \\
\quad<0.001)\end{array} \\
\text { Median survival: } \\
\text { - } \quad \text { Segmentectomy } 71.4 \text { months } \\
\text { - } \quad \text { Wedge } 58.0 \text { months }(P< \\
\quad \text { O.001) } \\
\text { Tumors } \leq 2 \mathrm{~cm}: \\
\text { - SBRT median } 45.0 \text { months } \\
\text { - SLR } 67.5 \text { months }(H R=1.626 ; \\
\text { 95\%Cl: } 1.538-1.720 ; P<0.001)\end{array}$ & $\begin{array}{l}\text { SLR may be associated } \\
\text { with increased survival in patients } \\
\text { with stage I NSCLC } \\
\text { compared with SBRT } \\
\text { Other variables } \\
\text { such as cardiopulmonary function } \\
\text { probably play a role in treatment } \\
\text { selection and may affect survival }\end{array}$ \\
\hline $\begin{array}{l}\text { Cao et al. }{ }^{[7]} \text { (2019) (USA) } \\
\text { Meta-analysis (level } \\
\text { evidence 1) }\end{array}$ & 23 studies in NSCLC & $\begin{array}{l}\text { Overall survival: } \\
\text { - } \quad \text { higher in SLR than SABR in } \\
\text { unmatched patients from } 6 \\
\text { studies }(O R=1.54 ; 95 \% C l: \\
\text { 1.36-1.75; } P<0.00001)\end{array}$ & $\begin{array}{l}\text { Surgery might be superior to SBRT } \\
\text { in terms of mid- and long-term } \\
\text { clinical outcomes } \\
\text { SBRT is associated with lower } \\
\text { perioperative mortality } \\
\text { Improved outcomes after surgery, } \\
\text { may be attributable at least in } \\
\text { part to an imbalance of baseline } \\
\text { characteristics }\end{array}$ \\
\hline
\end{tabular}

NSCLC: non-small cell lung cancer; OS: overall survival; RFS: recurrence-free survival; SLR: sublobar resection; SABR: stereotactic ablative radiotherapy; SBRT: stereotactic body radiation therapy; DSS: disease-specific survival; CSS: cancer-specific survival 
safety profile, although the evidence is limited by the absence of randomized trials in this specific subset of patients. A multidisciplinary assessment in a tumor board with different professionals should guide the individual decision-making process.

\section{QUESTIONS THAT REMAIN UNANSWERED}

Some important topics should be investigated with emphasis to achieve quality levels of evidence in order to set the role of SLR and SABR in NSCLC treatment algorithms:

- Is SLR really an alternative to lobectomy in early stage NSCLC, and if so, which is its exact indications (e.g. tumor size, margin to tumor ratio, histological types and subtypes, radiological pattern, nodal assessment)?

- What is the role of wedge resection in stage I NSCLC and which patients benefit?

- Is SABR a real alternative to limited resection in patients with stage I NSCLC at high-risk for surgery?

- Should SABR be offered in operable stage I NSCLC now that minimally-invasive surgery and SLR are available?

- Regarding the limitations of SABR in nodal staging and the difficulties in surveillance of post-radiation lung scars, does patient age play a role in offering SABR during the decision-making process?

\section{CONCLUSION}

High-quality multicenter and randomized studies comparing SLR with SABR in NSCLC treatment are missing. Retrospective and prospective comparative studies and series, and some meta-analysis or propensity score matching studies show that SABR is a potential alternative treatment for in stage I NSCLC patients. A trend towards better survival and local control has been found with SLR, but lower adverse effects profile makes SABR an attractive alternative, especially when dealing with patients at high-risk or inoperable stage I NSCLC, so it should be included in the decision-making process.

\section{DECLARATIONS}

\section{Authors' contributions}

Review and writing: Galvez C

Conception and design of the study: Galvez C, Bolufer S, Corcoles JM, Lirio F, Sesma J, Mafe JJ, Cerezal J

\section{Availability of data and materials}

Not applicable.

\section{Financial support and sponsorship}

None.

\section{Conflicts of interest}

All authors declared that there are no conflicts of interest.

\section{Ethical approval and consent to participate}

Not applicable.

\section{Consent for publication}

Not applicable.

\section{Copyright}

(c) The Author(s) 2020. 


\section{REFERENCES}

1. Press release no 263. International Agency for Research on Cancer. World Health Organization (WHO) 2018. Available from: https:// www.who.int/ionizing_radiation/research/iarc/en/. [Last accessed on 23 Nov 2020]

2. Goldstraw P, Chansky K, Crowley J, et al. The IASLC lung cancer staging project: proposals for revision of the TNM stage groupings in the forthcoming (eighth) edition of the TNM classification for lung cancer. $J$ Thorac Oncol 2016;11:39-51.

3. Ginsberg RJ, Rubinstein LV. Randomized trial of lobectomy versus limited resection for T1 N0 non-small cell lung cancer. Ann Thorac Surg 1995;60:615-22

4. Bao F, Ye P, Yang Y, et al. Segmentectomy or lobectomy for early stage lung cancer: a meta-analysis. Eur J Cardio-thoracic Surg 2014;46:1-7.

5. Dziedzic R, Zurek W, Marjański T, et al. Stage I non-small-cell lung cancer: long-term results of lobectomy versus sublobar resection from the polish national lung cancer registry. Eur J Cardio-thoracic Surg 2017;52:363-9.

6. Song CY, Sakai T, Kimura D, Tsushima T, Fukuda I. Comparison of perioperative and oncological outcomes between video-assisted segmentectomy and lobectomy for patients with clinical stage IA non-small cell lung cancer: a propensity score matching study. $J$ Thorac Dis 2018;10:4891-901.

7. Cao J, Yuan P, Wang Y, et al. Survival rates after lobectomy, segmentectomy, and wedge resection for non-small cell lung cancer. Ann Thorac Surg 2018;105:1483-91.

8. Moon MH, Moon YK, Moon SW. Segmentectomy versus lobectomy in early non-small cell lung cancer of $2 \mathrm{~cm}$ or less in size: a population-based study. Respirology 2018;23:695-703.

9. Ackerson BG, Tong BC, Hong JC, et al. Stereotactic body radiation therapy versus sublobar resection for stage I NSCLC. Lung Cancer 2018;125:185-91.

10. Hiraki T, Gobara H, Mimura H, Matsui Y, Toyooka S, Kanazawa S. Percutaneous radiofrequency ablation of clinical stage I non-small cell lung cancer. $J$ Thorac Cardiovasc Surg 2011;142:24-30.

11. Nagata Y, Hiraoka M, Shibata T, et al. Prospective trial of stereotactic body radiation therapy for both operable and inoperable T1N0M0 non-small cell lung cancer: Japan Clinical Oncology Group Study JCOG0403. Int J Radiat Oncol Biol Phys 2015;93:989-96.

12. Tandberg DJ, Tong BC, Ackerson BG, Kelsey CR. Surgery versus stereotactic body radiation therapy for stage I non-small cell lung cancer: a comprehensive review. Cancer 2018;124:667-78.

13. Nyman J, Hallqvist A, Lund JÅ, et al. SPACE - a randomized study of SBRT vs conventional fractionated radiotherapy in medically inoperable stage I NSCLC. Radiother Oncol 2016;121:1-8.

14. Li C, Wang $\mathrm{L}, \mathrm{Wu} \mathrm{Q}$, et al. A meta-analysis comparing stereotactic body radiotherapy vs conventional radiotherapy in inoperable stage $\mathrm{I}$ non-small cell lung cancer. Medicine (Baltimore) 2020;99:e21715.

15. Falkson CB, Vella ET, Yu E, et al. Radiotherapy with curative intent in patients with early-stage, medically inoperable, non-small-cell lung cancer: a systematic review. Clin Lung Cancer 2017;18:105-21.e5.

16. Varlotto J, Fakiris A, Flickinger J, et al. Matched-pair and propensity score comparisons of outcomes of patients with clinical stage i nonsmall cell lung cancer treated with resection or stereotactic radiosurgery. Cancer 2013;119:2683-91.

17. Timmerman RD, Paulus R, Galvin J, et al. Stereotactic body radiation therapy for medically inoperable early-stage lung cancer patients. JAMA 2010;303:1070-6.

18. Harris AA, Stang K, Small C, et al. Pretreatment factors influencing radiation pneumonitis after stereotactic body radiation therapy in the treatment of lung cancer. Cureus 2020;12.

19. Morias S, Marcu LG, Short M, et al. Treatment-related adverse effects in lung cancer patients after stereotactic ablative radiation therapy. J Oncol 2018;2018:6483626.

20. Wink KCJ, van Baardwijk A, Troost EGC, De Ruysscher D. Nodal recurrence after stereotactic body radiotherapy for early stage nonsmall cell lung cancer: incidence and proposed risk factors. Cancer Treat Rev 2017;56:8-15.

21. Altorki NK, Kamel MK, Narula N, et al. Anatomical segmentectomy and wedge resections are associated with comparable outcomes for patients with small cT1N0 non-small cell lung cancer. J Thorac Oncol 2016;11:1984-92.

22. Gossot D, Lutz J, Grigoroiu M, Brian E, Seguin-Givelet A. Thoracoscopic anatomic segmentectomies for lung cancer: technical aspects. J Vis Surg 2016;2:171.

23. Guo Z, Yin W, Pan H, et al. Video-assisted thoracoscopic surgery segmentectomy by non- intubated or intubated anesthesia : a comparative analysis of short-term outcome. J Thorac Dis 2016;8:359-68.

24. Hung MH, Hsu HH, Chan $\mathrm{KC}$, et al. Non-intubated thoracoscopic surgery using internal intercostal nerve block, vagal block and targeted sedation. Eur J Cardiothorac Surg 2014;46:620-5.

25. Charloux A, Quoix E. Lung segmentectomy: does it offer a real functional benefit over lobectomy? Eur Respir Rev 2017;26:170079.

26. Traibi A, Grigoroiu M, Boulitrop C, et al. Predictive factors for complications of anatomical pulmonary segmentectomies. Interact Cardiovasc Thorac Surg 2013;17:838-44.

27. Ettinger DS, Wood DE, Aggarwal C. NCCN clinical practice guidelines in oncology (NCCN Guidelines ${ }^{\circledR}$ ) guideline non-small cell lung cancer version 7. 2019. Available from: https://jnccn.org/view/journals/jnccn/17/12/article-p1464.xml?print\&print\&print. [Last accessed on 3 Dec 2020]

28. Vansteenkiste J, Crino L, Dooms C, et al. 2nd ESMO consensus conference on lung cancer: early stage non-small cell lung cancer consensus on diagnosis, treatment and follow-up. Ann Oncol 2014;25:1462-74.

29. Nakamura K, Saji H, Nakajima R, et al. A phase III randomized trial of lobectomy versus limited resection for small-sized peripheral nonsmall cell lung cancer (JCOG0802/WJOG4607L). Jpn J Clin Oncol 2009;40:271-4. 
30. Linden D, Linden K, Oparka J. In patients with resectable non-small-cell lung cancer, is video-assisted thoracoscopic segmentectomy a suitable alternative to thoracotomy and segmentectomy in terms of morbidity and equivalence of resection? Interact Cardiovasc Thorac Surg 2014;19:107-10.

31. Linden D, Linden K, Oparka J. In patients with resectable non-small-cell lung cancer, is video-assisted thoracoscopic segmentectomy a suitable alternative to thoracotomy and segmentectomy in terms of morbidity and equivalence of resection? Interact Cardiovasc Thorac Surg 2014;19:107-10.

32. Ohtaki Y, Shimizu K. Anatomical thoracoscopic segmentectomy for lung cancer. Gen Thorac Cardiovasc Surg 2014;62:586-93.

33. Veronesi G. Robotic lobectomy and segmentectomy for lung cancer: results and operating technique. J Thorac Dis 2015;7:S122-30.

34. Schneider BJ, Daly ME, Kennedy EB, Stiles BM. Stereotactic body radiotherapy for early-stage non?small-cell lung cancer: American society of clinical oncology endorsement of the American society for radiation oncology evidence-based guideline summary. $J$ Oncol Pract 2018;14:180.

35. Tamura M, Matsumoto I, Tanaka Y, et al. Comparison between stereotactic radiotherapy and sublobar resection for non-small cell lung cancer. Ann Thorac Surg 2019;107:1544-50.

36. Yendamuri S, Komaki RR, Correa AM, et al. Comparison of limited surgery and three-dimensional conformal radiation in high-risk patients with stage I non-small cell lung cancer. J Thorac Oncol 2007;2:1022-8.

37. Puri V, Crabtree T, Kymes S, et al. A comparison of surgical intervention and stereotactic body radiation therapy for stage i lung cancer in high-risk patients: a decision analysis. J Thorac Cardiovasc Surg 2012;143:428-36.

38. Grills IS, Mangona V, Welsh R, et al. Outcomes after stereotactic lung radiotherapy or wedge resection for stage I non-small-cell lung cancer (NSCLC). J Clin Oncol 2010;28:928-35.

39. Forquer J, McGarry R, Kesler K, et al. A matched-pair analysis of sublobar resection and stereotactic body radiotherapy (SBRT) for stage I NSCLC. Int J Radiat Oncol Biol Phys 2007;69:S492-3.

40. Matsuo Y, Chen F, Hamaji M, et al. Comparison of long-term survival outcomes between stereotactic body radiotherapy and sublobar resection for stage i non-small-cell lung cancer in patients at high risk for lobectomy: a propensity score matching analysis. Eur J Cancer 2014;50:2932-8.

41. Fernando HC, Timmerman RD. American College of Surgeons Oncology Group Z4099/Radiation Therapy Oncology Group 1021: a randomized study of sublobar resection compared with stereotactic body radiotherapy for high-risk stage I non-small cell lung cancer. $J$ Thorac Cardiovasc Surg 2012;144:S35-8.

42. Mahmood S, Bilal H, Faivre-Finn C, Shah R. Is stereotactic ablative radiotherapy equivalent to sublobar resection in high-risk surgical patients with Stage I non-small-cell lung cancer? Interact Cardiovasc Thorac Surg 2013;17:845-53.

43. Scanagatta P. Is surgery still worthwhile as compared to stereotactic ablative radiotherapy or CyberKnife in high-risk surgical patients with stage I non-small-celllung cancer? E-comment. Interact Cardiovasc Thorac Surg 2013;17:853.

44. Snee MP, McParland L, Collinson F, et al. The SABRTooth feasibility trial protocol: a study to determine the feasibility and acceptability of conducting a phase III randomised controlled trial comparing stereotactic ablative radiotherapy (SABR) with surgery in patients with peripheral stage I non. Pilot Feasibility Stud 2016;2:5.

45. Ettinger DS, Wood DE, Aisner DL, et al. Non-Small cell lung - NCCN clinical practice guidelines in oncology, v1 2021.

46. Onishi H, Shirato H, Nagata Y, et al. Stereotactic body radiotherapy (SBRT) for operable stage I non-small-cell lung cancer: can SBRT be comparable to surgery? Int J Radiat Oncol Biol Phys 2011;81:1352-8.

47. Deng HY, Wang YC, Ni PZ, et al. Radiotherapy, lobectomy or sublobar resection? A meta-analysis of the choices for treating stage I nonsmall-cell lung cancer. Eur J Cardio-thoracic Surg 2017;51:203-10.

48. Chen H, Laba JM, Boldt RG, et al. Stereotactic ablative radiation therapy versus surgery in early lung cancer: a meta-analysis of propensity score studies. Int J Radiat Oncol Biol Phys 2018;101:186-94.

49. Iguchi T, Hiraki T, Matsui $Y$, et al. Survival outcomes of treatment with radiofrequency ablation, stereotactic body radiotherapy, or sublobar resection for patients with clinical stage I non-small-cell lung cancer: a single-center evaluation. $J$ Vasc Interv Radiol 2020;31:1044-51.

50. Bryant AK, Mundt RC, Sandhu AP, et al. Stereotactic body radiation therapy versus surgery for early lung cancer among US veterans. Ann Thorac Surg 2018;105:425-31.

51. Wu J, Bai HX, Chan L, et al. Sublobar resection compared with stereotactic body radiation therapy and ablation for early stage non-small cell lung cancer: a national cancer database study. J Thorac Cardiovasc Surg 2020;160:1350-7.e11.

52. Videtic GM, Donington J, Giuliani M, et al. Stereotactic body radiation therapy for early stage non-small cell lung cancer: executive summary of an ASTRO evidence-based guideline. Pract Radiat Oncol 2017;7:295-301.

53. Gierada D, Pinsky P. Survival after detection of stage I lung cancer by screening in the national lung screening trial. Chest 2020;3:34234-5.

54. Horeweg N, Scholten ET, de Jong PA, et al. Detection of lung cancer through low-dose CT screening (NELSON): a prespecified analysis of screening test performance and interval cancers. Lancet Oncol 2014;15:1342-50.

55. Senan S, Paul MA, Lagerwaard FJ. Treatment of early-stage lung cancer detected by screening: surgery or stereotactic ablative radiotherapy? Lancet Oncol 2013;14:e270-4.

56. Swensen S, Silverstein M, Ilstrup D, et al. The probability of malignancy in solitary pulmonary nodules: application to small radiologically indeterminate nodules. Arch Intern Med 1997;157:849-55.

57. Palma D, Lagerwaard F, Rodrigues G, Haasbeek C, Senan S. Curative treatment of Stage i non-small-cell lung cancer in patients with severe COPD: stereotactic radiotherapy outcomes and systematic review. Int J Radiat Oncol Biol Phys 2012;82:1149-56. 